\title{
İlkokul ve Ortaokul Öğretmenlerinin Örgütsel Vatandaşlık Davranışları ile Örgütsel Sosyalleşme Davranışları Arasındaki İlişkinin İncelenmesi
}

\author{
Investigation of Relationship Between Organizational Citizenship Behaviors and \\ Organizational Socialization Behaviors of Primary School and Jonior
}

\section{Tuncay Yavuz ÖZDEMİ* Mustafa ORHAN ${ }^{* *}$}

\begin{abstract}
Öz
$\mathrm{Bu}$ araştırmanın amac1, ilkokul ve ortaokul öğretmenlerinin örgütsel vatandaşlık ve örgütsel sosyalleşme davranışlarına ilişkin görüşlerini belirleyerek, bu görüşlerin cinsiyet, okul türü ve branş değişkenlerine göre anlamlı biçimde farklılaşıp farklılaşmadığını belirlemeye çalışmaktır. Bununla birlikte, ilkokul ve ortaokul öğretmenlerinin örgütsel vatandaşlık davranışları ile örgütsel sosyalleşme davranışları arasındaki ilişkinin belirlenmesi de amaçlanmıştır. Bu araştırmanın örneklemini 2016-2017 eğitim-öğretim yılında Erzurum ili Yakutiye ilçesinde görevli 384 ilkokul ve ortaokul öğretmeni oluşturmaktadır. Araştırma ilişkisel tarama modelindedir. Araştırma verilerini toplamak için DiPaola, Tarter ve Hoy (2005) tarafından geliştirilen, Türkçe’ye uyarlaması ile geçerlik ve güvenirliği Taştan ve Yılmaz (2008) tarafından yapılan "Örgütsel Vatandaşlık Ölçeği” ile Erdoğan (2012) tarafından geliştirilen “Örgütsel Sosyalleşme Ölçeği” kullanılmıştır. Araştırma sonuçlarına göre ilkokul ve ortaokul öğretmenlerinin örgütsel vatandaşlık davranışlarına ilişkin görüşleri ile cinsiyet, okul türü ve branş değişkenlerine göre anlamlı bir farklılık bulunmamıştır. İlkokul ve ortaokul öğretmenlerinin örgütsel sosyalleşme davranışlarına ilişkin görüşleri ile cinsiyetleri arasında "örgüt dili ve tarihi" boyutunda erkek öğretmenler lehine; okul türü arasında "kişilerarası ilişkiler", "örgüt dili ve tarihi”, "örgüt politikası", "amaç ve değerlere uyum” boyutları ve örgütsel sosyalleşmenin toplamında ilkokul öğretmenleri lehine; branşları arasında "mesleki yeterlik" boyutu dışında bütün boyutlarda ve örgütsel sosyalleşmenin toplamında sınıf öğretmenleri lehine anlamlı farklılık bulunmuştur. İlkokul ve ortaokul öğretmenlerinin örgütsel
\end{abstract}

* Yrd. Doç. Dr., Fırat Üniversitesi, Eğitim Fakültesi, Eğitim Bilimleri Bölümü, tyozdemir@firat.edu.tr

** Öğretmen, Erzurum İl Milli Eğitim Müdürlüğü, mustafaorhan2525@hotmail.com 
vatandaşlık ve örgütsel sosyalleşme algıları (alt boyutlar toplamı) arasında orta düzeyde pozitif yönlü anlamlı bir ilişki olduğu tespit edilmiştir. Ayrıca; "kişilerarası ilişkiler" ile "amaç ve değerlere uyum” değişkenlerinin birlikte, örgütsel vatandaşlı̆̆ı anlamlı bir şekilde yordadığı tespit edilmiştir.

Anahtar Kelimeler: Örgütsel Vatandaşlık, Örgütsel Sosyalleşme, İlkokul, Ortaokul, Öğretmen

\begin{abstract}
The aims of this research are to investigate the opinions of elemantary school and secondary school teachers regarding organizational citizenship and organizational socialization behaviors and to determine whether these opinions differ significantly according to gender, school type and branch variables. In addition, it was aimed to examine the relationship between organizational citizenship behaviors and organizational socialization behaviors of primary and secondary school teachers. The sample of this research consists of 384 primary and secondary school teachers working in the Yakutiye district of Erzurum province in 2016-2017 educational year. The research uses a correlational survey model. "Organizational Socialization Scale" developed by Erdoğan (2012) and the "Organizational Citizenship Scale" translated by Taştan and Yilmaz (2008) anddeveloped by DiPaola, Tarter and Hoy (2005) are used. According to the results of the research, there were no significant differences between the opinions of elementary and secondary school teachers regarding their organizational citizenship behaviors and gender, school type and branch variables.The opinions of elementary and secondary school teachers regarding their organizational socialization behaviors and their genders are "organization language and history" in favor of male teachers; in favor of elementary school teachers in the sum of "interpersonal relations", "organization language and history", "organizational policy", dimensions of "adaptation to goals and values" and organizational socialization among school types; there was a significant difference in all dimensions except for the "professional competence" dimension among branches and in the sum of organizational socialization in favor of class teachers. It was found that there was a moderately positive relationship between organizational citizenship and organizational socialization perceptions (sum of sub dimensions) of primary and secondary school teachers. Also; It has been found that "interpersonal relations" and "adaptation to goals and values" together have a significant effect on organizational citizenship.
\end{abstract}

Keywords: Organizational Citizenship, Organizational Socialization, Primary School, Secondary School, Teacher

\title{
Giriş
}

\section{Örgütsel Vatandaşık}

Örgütlerde kimi işgörenler, örgütsel hak ve sorumluluklarını dengede tutarak, sadece kendi sorumluluk alanlarına giren görevleri icra ederlerken; kimi işgörenler ise yetenek ve tecrübelerini sorumluluklarının yanında farklı alanlarda da kullanmaya istekli olabilmektedirler. Günümüzde işverenler, işgörenlerinden tanımlanmış ve yapılması zorunlu olan davranışlar dışında kişinin kendi işiymiş gibi sahiplendiği davranışlarda bulunmalarını beklemektedir (Yıldırım, 2017). İşgörenlerin yetenek ve tecrübelerini görev alanlarıyla sınırlı tutmayarak farklı alanlara 
aktarmasıyla ilgili olan örgütsel vatandaşlık davranışları, işgörenlerin belirlenmiş rollerinin ötesindeki beklentileri de aşan ve isteyerek sergiledikleri fazladan davranışlarını ifade eder (Allison, Voss \& Dryer, 2001). Benzer şekilde örgütsel vatandaşlık davranışları; resmi/biçimsel ödül sistemi tarafından doğrudan ve açıkça tanımlanmayan, örgütün etkin işleyişini teşvik eden, isteğe bağlı (Organ, Podsakoff ve MacKenzie, 2006), işlevsel, ekstra rol, prososyal davranışlar olarak bireye, gruba ya da örgüte yöneltilen, örgüt tarafından resmi olarak belirlenmeyen, herhangi bir ceza ya da ödülün olmadığı yardımcı davranışlar (Sharma, Bajpai \& Holani, 2011) olarak tanımlanabilir. Dolayısıyla herhangi bir karşllık beklemeden kendisine verilen görevleri ve daha fazlasını gönüllü olarak yapan, huzurlu bir iş ortamı için çabalayan, örgütüne değer veren ve gönül bağı hisseden işgörenin davranışları örgütsel vatandaşılı davranışlarına bir örnektir (Demiröz, 2014).

Biçimsel rol davranışları, daha çok işgörenlerin iş tanımlarının çerçevesinde görevlerini yerine getirirken, karşılığında ödül veya ceza aldıkları eylem ve davranışlar olarak tanımlanır (Ürek, 2015). Fazladan rol davranışları, normalde işgörenlerin iş tanımlarında bulunmamakla birlikte, örgütü destekleyen görev rolleri dışındaki davranışlardır (Demirel, Seçkin ve Özçınar, 2011). Fazladan rol davranışları, örgütsel amaçlara katkıda bulunmak amacıyla örgüte, gruba ya da bireye yönelik belirlenmiş rol gerekliliklerinin ötesinde olan davranışlar olup (Somech \& Drach-Zahavy, 2000), biçimsel olmayan ortak eylemleri, gönüllü davranışları ve yardımseverliği içermektedir (Çetin, Yeşilbağ ve Akdağ, 2003).

Örgütsel vatandaşlık davranışları ile ilgili araştırmalarda literatürde en çok Organ’ın (1988), beş boyutlu tanımlamasından yararlanılmıştır. Bu boyutlar şunlardır:

- Özgecilik: İşgörenlerin, diğer işgörenlere yardım etmesi, onların karşılaştığı sorunların çözümüne yönelik gönüllü tutum ve davranışlarıdır (Demirel vd, 2011). Bu boyutta, işin yapılması için gereken başarıyı gösteremeyen veya işini yapmada zorlanan işgörene yardım etme davranışı ön plandadır (Sezgin, 2005).

- Vicdanlılık: Kimsenin izleyemediği durumlarda dahi işgörenlerin örgütsel kurallara ve usullere tam olarak uymaları (Bukhari, 2008), katılım, dakiklik, temizlik, kaynakları saklama ve işe standartların üstünde devam etmede gerekli olan asgari düzeylerin ötesine gitmeleridir (Özdemir, 2010).

- Sportmenlik: Örgütteki işgörenler arasında gerginlik yaratacak her türlü olumsuzlukları tolere etme anlamına gelip (Özdevecioğlu, 2003), işgörenlerin işe ve örgüt kültürüne yönelik olumlu bir bakış açısı edinmelerini ve karşılaşılan sorunları aşarak, istekli bir şekilde çalışmalarını ifade eder (Sezgin, 2005). Podsakoff, MacKenzie, Paine ve Bachrach (2000)'e göre sportmenlik davranışını sergileyen işgörenler sadece diğerleri tarafından rahatsız edildiklerinde şikayet etmemekle kalmayan; aynı zamanda işler yolunda gitmediğinde de olumlu tutumlarını sürdüren, diğerleri önerilerini takip etmediklerinde gücenmeyen, kişisel çıkarlarını çalışma grubunun iyiliği için feda eden ve fikirlerinin reddedilmesini kişisel olarak algılamayan kişilerdir. 
- Nezaket: İşs sorumluluklarından dolayı sürekli etkileşim içinde olan, birbirlerinin iş ve kararlarından etkilenen işgörenlerin sergiledikleri olumlu davranışlardır (Güven, 2006). Bu tür davranışlar örgütsel iletişim sistemini geliştirir, ortaya çıkacak problemleri önlemeye yardımcı olur ve problemleri azaltabilir (Walz \& Niehoff, 2000).

- Sivil erdem: İşgörenlerin sorumluluk olarak örgütteki politik süreçlere katılımları ve örgüt yaşamına dair düşünmeleriyle ilgilidir. Bu boyut örgüt toplantılarına gönüllü ve aktif katılımı, çözüm önerilerinin getirilmesini, alınan kararların uygulanmasında etkin olunması gibi davranışları ifade eder (Gök, 2007). Ancak bu davranışların, daha çok işgörenlere inisiyatif veren, onlara yetki ve sorumluluk devreden örgütlerde görüldüğü söylenebilir (Doğrul, 2013).

Örgütsel vatandaşlık davranışları örgütsel öğrenmeyi desteklemekte, öğrenci başarısını artırmaktadır (Polat, 2007). Örgütsel vatandaşılı davranışlarını sergileyen öğretmenler yenilikçi önerilerde bulunmakta, müfredat dışı etkinliklere gönüllü olarak destek vermekte, yeni kurullarda görev yapmaya gönüllü olmakta, öğrencilere kendilerine ait zamanlarında yardım etmekte, gerekirse yardım etmek için okuldan sonra kalmakta ve öğrencilere yoğun görevler verilmesi isteğine karşı koymaktadırlar (DiPaola \& Hoy, 2005). Aynı zamanda vatandaşlık davranışları okulun genel etkinliğine katkıda bulunmakta ve yönetici rolünün idarecilik yönünü azaltmaktadir (DiPaola \& Tschannen-Moran, 2001).

\section{Örgütsel Sosyalleşme}

Bir örgütün gelişim ve değişimi ancak örgütsel amaçların başarılmasıyla mümkün olmaktadır. $\mathrm{Bu}$ doğrultuda işgörenlerin örgütleriyle aynı değer, ilke ve normları paylaşmaları önemlidir. Örgütler kendi içlerinde bir iç uyuma gidemezlerse örgütsel amaçlar gerçekleştiremeyeceklerdir (Eren, 2014). Bu bakımdan örgütsel amaçların gerçekleşmesi, örgütsel ve bireysel tutum ile değer ve davranışların uyumuna bağlıdır (Can, 1999). Örgüt-işgören uyumuyla işgörenlerin daha iyi tatmin olması ve daha iyi performans göstermesi sağlanacağı gibi aynı zamanda örgütün daha etkili olması da mümkün olacaktır (Ostroff ve Rothausen, 1997).

Örgüte yeni katılan birey için örgüt birtakım belirsizlikleri içeren bir yapıdır. Bireyin hem örgütteki belirsizliklerle mücadele edebilmesinde, hem örgüt değerlerine uyum sağlanmasında hem de mesleki yeterliliğinin artırılmasında yapılacak sosyalleşme çalışmaları önem kazanmaktadır. Sosyalleşme sürecinin, işgörenin örgüte uyumunun sağlanmasında, onun örgüt değer, norm ve tutumlara uygun hareket edebilmesinde çok önemli bir yeri bulunmaktadır. İşgörenin iş doyumu ve örgütsel amaçlarının gerçekleştirilmesi örgütsel sosyalleşme sürecinin etkililiğine bağlıdır (Kartal, 2008).

Sosyalleşme kavramının sosyal, kültürel, politik, ekonomik, antropolojik, psikolojik, yönetsel ve felsefi yönleri bulunmakta, konusu olduğu bilim dalı ve boyutuna göre farklı tanımları söz konusu olmaktadır (Balcı, 2003). Aynı zamanda sosyalleşme kavramıyla aynı anlamı ifade eden toplumsallaşma ve sosyalizasyon gibi kullanımlar da bulunmaktadır. Sosyalleşme kavramı; bireylerin içinde bulundukları sosyal grup ve toplum tarafından oluşturulmuş normları ve 
kuralları öğrenmesi veya kabul etmesi süreci (Çalık, 2003), bireyin doğumundan itibaren içinde yaşadığı toplumun üyeliğini kazanmasında geçirdiği aşamalar (Doğan, 2011), örgütlenmiş sosyal yaşamın kabul edilmiş ve onaylanmış yollarına uyarlandığı bir süreç (Oktay, 2000), bireyin, toplumun norm ve değerlerini içselleştirerek toplumsal rolleri yerine getirdiği, topluma uyum sağlama yeteneği kazandığı bir öğrenme sürecidir (Esgin, 2014). Genel olarak sosyalleşme, bireysel-toplumsal ilişkilerin aracılık ettiği merkezi bir süreç olarak düşünülebilir. Daha dar bir şekilde ise, yeni üyelerin örgüt üyeleri haline geldiği bir süreç olarak incelenmektedir (Bullis, 1993).

Örgüte yeni katılan bireyin dışarıdan biri olmaktan çıkıp örgütün içindekilerden birisi olmasını öngören örgütsel sosyalleşme, bireyin yeni bir durumun parçası olduğu bir değişim sürecidir (Balc1, 2003). Örgütsel sosyalleşme yeni örgütsel pozisyon, statü veya rollerini öğrenen insanların deneyimlerinin örgüt içindeki diğer insanlar tarafından yapılandırılma biçimini ifade eder (Van Maanen, 1978). Aynı zamanda örgütsel sosyalleşme, örgüte dışarıdan katılanların etkili üyelere dönüştürüldüğü bir süreç (Feldman, 1976), örgüte yeni katılanlar ile örgütlerin aynı norm ve değerleri paylaşmasını sağlamaya yönelik faaliyetler (Gürbüz, 2013), bireylerin değerleri, beklenen davranışları ve örgüt içerisindeki rollerini yerine getirmeleri için gerekli sosyal bilgiyi öğrendikleri süreç (Kırel, 2010), işgörenin değer, norm, kural ve uygulamaya yönelik ilkeleri öğrenmesi, tanıması ve kültürlenmesi (Çelik, 1998) "kuralları öğrenme", telkin edilme ve eğitilme, bir örgütte ya da bazı alt birimlerinde nelerin önemli olduğunu öğretme süreci (Can, Azizoğlu ve Aydın, 2011) olarak da ifade edilmektedir. Genel olarak örgütsel sosyalleşme, işgörenin örgütte özel bir role adapte edildiği öğrenme içeriği ve süreci ile ilgilidir (Ge, Su ve Zhou, 2010).

Örgüte yeni dahil olan işgörenler, örgütle ilgili yeni ve farklı özelliklerle karşılaşırlar, bilgi kaynaklarını araştırıp, örgüte dair karşılaştıkları özelliklerden hangilerinin kendileri ile ilgili olduğunu öğrenmeye çalışırlar (Çalık, 2003). Örgüte yeni katılan üyeler, herhangi bir örgüt üyesi gibi, belirsizlikleri azaltarak iş ortamının daha öngörülebilir, anlaşılabilir ve sonuç olarak kontrol edilebilir hale getirilmesi için motive olmaktadırlar. Belirsizlik, çeşitli iletişim kanalları yoluyla sağlanan bilgiler vasıtasıyla; özellikle de üstler ve meslektaşlarla olan sosyal etkileşimlerle azaltılır (Saks \& Ashforth, 1997). Aynı zamanda, örgüt ya da grubun norm ve değerlerinin öğrenilmesinde yeni katılan bireyin birçok kaynağı kullandığı bilinmektedir. Bunlar arasında örgütün resmi mevzuat ve kaynakları, örgütteki anahtar durumundaki kişilerin model olmaları, öğreticilerin talimatları, kıdemli eş çalışanların örnek olmaları, örgüte yeni katılan çalışanın problem çözme ve deneme girişimlerinin ödüllendirilmesi ya da cezalandırılması, kıdemli çalı̧anların rehberlik ve açıklamaları bu kaynaklar arasında bulunmaktadır (Balcı, 2003). Bu bağlamda, sosyalleşme süreci yeni işgörenlerin yapacakları işleri ve rolleri konusundaki belirsizlikleri asgariye indirerek, örgüt iklimine ve çalışacakları iş çevresine uyum sağlamalarını kolaylaştıracak (Gürbüz, 2013), kendilerinden beklenenler hakkında bilgi sahibi olmalarını ve örgütte karşılaşacakları rol belirsizliğinden olumsuz şekilde etkilenmelerini önleyecektir (Yüksel, 2004).

Örgüte giren işgörenlerin sosyalleşmeleri için formal ve informal uygulamalar kullanılabilmektedir. Formal sosyalleşme, işgörenin kurumsal anlamda dizayn edilmiş bir eğitim-gelişim programına tabii tutulmasını içermektedir (Ergün ve Taşgit, 2011). İnformal 
sosyalleşmede ise; işgören işine ait pek çok bilgiyi deneme yanılma yolu ile öğrenmekte, görev yapacağı grubun bir parçası olarak, üzerine düşen görevleri kendisi yapmaktadır (Aknar, 2013).

Öğretmenlerin sosyalleşmesi; mesleki değer, tutum ve ilgilerini kabul etme ve bunların nasıl değiştirileceğini öğrenmeyi kapsar (Memduhoğlu, 2008). Öğrenimleri esnasında uygulamaya yönelik yeterince eğitim almayan öğretmenlerin işe başladıkları eğitim kurumlarında başarılı olmaları, dinamikliklerini korumaları ancak iyi bir sosyalleştirme süreci ile mümkündür (Özgan, 2013). Öğretmenler, eğitim örgütlerinin en önemli işgörenleri olup; onların örgütsel sosyalleşme düzeylerinin artırılması, okulların amaçlarını verimli ve etkili biçimde yerine getirmelerinde son derece önemli olmaktadır (Ylldız, 2012).

$\mathrm{Bu}$ araştırmada, ilkokul ve ortaokul öğretmenlerinin örgütsel vatandaşl1k ve örgütsel sosyalleşme davranışlarına ilişkin görüşlerini belirleyerek, bu görüşlerin cinsiyet, okul türü ve branş değişkenlerine göre anlamlı biçimde farklılaşıp farklılaşmadığı belirlenmeye çalışılmıştır. Bununla birlikte ilkokul ve ortaokul öğretmenlerinin örgütsel vatandaşlık davranışları ile örgütsel sosyalleşme davranışları arasındaki ilişkinin belirlenmesi amaçlanmıştır.

\section{Yöntem}

Bu araştırmanın yöntemi, ilişkisel tarama modelidir. İlişkisel tarama modeli, iki ve daha çok sayıdaki değişken arasında birlikte değişim varlığını ya da derecesini belirlemeyi amaçlayan araştırma yaklaşımıdır (Karasar, 2012).

\section{Araştırma Evreni ve Örneklemi}

Araştırmanın evrenini, 2016-2017 eğitim öğretim yllında Erzurum ili merkez Yakutiye İlçesỉndeki resmi ilkokul ve ortaokullarda görevli 1879 öğretmen oluşturmaktadır. Araştırmanın örneklemini basit seçkisiz tesadüfi örnekleme yöntemi ile 384 ilkokul ve ortaokul öğretmeni oluşturmaktadır. Basit seçkisiz örnekleme yöntemi, her bir örnekleme birimine eşit seçilme olasılığı vererek seçilen birimlerin örnekleme alındığı yöntemdir (Büyüköztürk, Çakmak, Akgün, Karadeniz ve Demirel, 2016). Tablo 1'de örneklemde yer alan öğretmenlerin demografik özelliklerine yer verilmiştir.

Tablo I

Illkokul ve Ortaokul Öğretmenlerinin Demografik Özelliklerine Göre Dağılımı

\begin{tabular}{cccc}
\hline \multicolumn{2}{c}{ Demografik Özellikler } & f & \% \\
\hline \multirow{2}{*}{ Cinsiyet } & Erkek & 156 & 40,6 \\
& Kadın & 228 & 59,4 \\
\hline \multirow{2}{*}{ Okul Türü } & İlkokul & 183 & 47,7 \\
& Ortaokul & 201 & 52,3 \\
\hline \multirow{2}{*}{ Branş } & Sinıf Öğretmeni & 160 & 41,7 \\
& Sözel Ders Öğr. & 149 & 38,8 \\
& Sayısal Ders Öğr. & 75 & 19,5 \\
\hline TOPLAM & & $\mathbf{3 8 4}$ & $\mathbf{1 0 0 . 0 0}$ \\
\hline
\end{tabular}


Tablo 1'de görüldüğü üzere görüşlerine başvurulan 384 öğretmenin, 156'sının $(\% 40,6)$ erkek, 228'inin $(\% 59,4)$ kadın olduğu, 183'ünün $(\% 47,7)$ ilkokulda, 201'inin (\%52,3) ortaokulda görev yaptığı 160 öğretmenin (\%41,7) sınıf öğretmenliği branşında, 149’unun (\%38,8) sözel branşlarda ve 75 öğretmenin de $(\% 19,5)$ sayısal branşlarda öğretmenlik yaptıkları belirlenmiştir.

\section{Veri Toplama Aracı}

Araştırma verilerinin toplanmasında Örgütsel Vatandaşlık Ölçeği ve Örgütsel Sosyalleşme Ölçeği kullanılmıştır. Aynı zamanda katılımcıların demografik özelliklerini belirleyebilmek için kişisel bilgi formundan yararlanılmıştır. Ölçeklere ilişskin bilgiler aşağıda sunulmuştur.

Örgütsel Vatandaşlık Ölçeği: DiPaola, Tarter ve Hoy (2005) tarafından geliştirilen, Türkçe’ye uyarlaması ile geçerlik ve güvenirliği Taştan ve Yılmaz (2008) tarafından yapılan ölçek, 12 maddeden oluşmaktadır. Ölçeğin orijinal formu tek boyuttan oluşmaktadır. Mevcut araştırmada elde edilen verilerin güvenirlik Cronbach Alpha değeri örgütsel vatandaşlık ölçeği için ,88 olduğu belirlenmiş, veri setinin yeterli düzeyde güvenilir olduğuna karar verilmiştir.

Örgütsel Sosyalleşme Ölçeği: Erdoğan (2012) tarafından geliştirilen ölçek, 24 maddeden oluşmaktadır. Örgütsel sosyalleşme ölçeğinde; mesleki yeterlik, kişilerarası ilişkiler, örgüt dili ve tarihi, örgüt politikası ile amaç ve değerlere uyum olmak üzere 5 boyut yer almaktadır. Mevcut araştırmada elde edilen verilerin güvenirlik Cronbach Alpha değeri örgütsel sosyalleşme ölçeği için ,93 olduğu belirlenmiş, veri setinin yeterli düzeyde güvenilir olduğuna karar verilmiştir.

\section{Verilerin Analizi}

Araştırmada elde edilen verilerin analizde frekans, yüzde, ortalama ve standart sapma değerleri hesaplanmış; cinsiyet, okul türü ve branş değişkenleri için t-testi ve tek yönlü varyans analizi uygulanmıştır. Katılımcıların örgütsel vatandaşlık ile örgütsel sosyalleşme ve alt boyutları arasındaki ilişkiyi belirlemek amacıyla korelasyon analizi yapılmış, onların örgütsel sosyalleşme ve alt boyutlarına ilişkin algılarının örgütsel vatandaşlık davranışlarını ne ölçüde açıklayabildiğini belirlemek amacıyla regresyon analizi kullanılmıştır.

\section{Bulgular}

Bu bölümde çalışmanın amaçları doğrultusunda elde edilen veriler ışı̆̆ında araştırmanın alt problemlerine ilişkin analiz bulguları sunulmuştur. Öğretmen görüşlerinin cinsiyet değişkenine göre analizi Tablo 2'de verilmiştir. 


\section{Tablo 2}

Illkokul ve Ortaokul Öğretmenlerinin Örgütsel Vatandaşlık ve Örgütsel Sosyalleşme Düzeylerine Illişkin Görüşlerinin Cinsiyet Değişkenine Göre Analizi

\begin{tabular}{|c|c|c|c|c|c|c|c|c|}
\hline Ölçekler & Boyutlar & Cinsiyet & $\mathrm{N}$ & $\bar{x}$ & SS & sd & $\mathrm{t}$ & $\mathrm{p}$ \\
\hline \multirow{2}{*}{$\begin{array}{c}\text { Örgütsel } \\
\text { Vatandaşlık }\end{array}$} & & Erkek & 156 & 3,85 &, 54 & \multirow{2}{*}{382} & \multirow{2}{*}{,- 849} & \multirow{2}{*}{,397 } \\
\hline & & Kadın & 228 & 3,90 &, 51 & & & \\
\hline \multirow{12}{*}{$\begin{array}{c}\text { Örgütsel } \\
\text { Sosyalleşme }\end{array}$} & \multirow{2}{*}{ Mesleki yeterlik } & Erkek & 156 & 4,26 &, 50 & \multirow{2}{*}{382} & \multirow{2}{*}{1,546} & \multirow{2}{*}{, 123} \\
\hline & & Kadın & 228 & 4,18 &, 51 & & & \\
\hline & \multirow{2}{*}{ Kişilerarası ilişkiler } & Erkek & 156 & 4,14 &, 51 & \multirow{2}{*}{382} & \multirow{2}{*}{1,709} & \multirow{2}{*}{,088 } \\
\hline & & Kadın & 228 & 4,05 &, 53 & & & \\
\hline & \multirow{2}{*}{ Örgüt dili ve tarihi } & Erkek & 156 & 3,77 &, 74 & \multirow{2}{*}{382} & \multirow{2}{*}{2,184} & \multirow{2}{*}{, 030} \\
\hline & & Kadın & 228 & 3,60 &, 76 & & & \\
\hline & \multirow{2}{*}{ Örgüt politikası } & Erkek & 156 & 4,16 & 49 & \multirow{2}{*}{382} & \multirow{2}{*}{, 043} & \multirow{2}{*}{ 965 } \\
\hline & & Kadın & 228 & 4,15 &, 54 & & & \\
\hline & \multirow{2}{*}{$\begin{array}{c}\text { Amaç ve değerlere } \\
\text { uyum uuuuuyum } \\
\text { uyum }\end{array}$} & Erkek & 156 & 4,35 &, 57 & \multirow[b]{2}{*}{382} & \multirow[b]{2}{*}{,908 } & \multirow[b]{2}{*}{,365 } \\
\hline & & Kadın & 228 & 4,30 &, 55 & & & \\
\hline & \multirow{2}{*}{ Toplam } & Erkek & 156 & 4,15 &, 44 & \multirow{2}{*}{382} & \multirow{2}{*}{1,711} & \multirow{2}{*}{,088 } \\
\hline & & Kadın & 228 & 4,07 &, 45 & & & \\
\hline
\end{tabular}

${ }^{*} \mathrm{p}<0,05$

Tablo 2'de, örgütsel vatandaşlık davranışlarına yönelik öğretmen görüşleri incelendiğinde ( $\mathrm{t}=$ ,849; p=,397), cinsiyet değişkenine göre erkek ve kadın öğretmenlerin görüşleri arasında anlamlı bir fark bulunmamıştır.

Örgütsel sosyalleşmenin "mesleki yeterlik" ( $\mathrm{t}=1,546 ; \mathrm{p}=, 123)$, "kişilerarası ilişkiler” ( $\mathrm{t}=1,709$; $\mathrm{p}=$,088), “örgüt politikası" ( $\mathrm{t}=, 043 ; \mathrm{p}=, 965)$ ve "amaç ve değerlere uyum" ( $\mathrm{t}=, 908 ; \mathrm{p}=, 365)$ boyutları ile örgütsel sosyalleşmenin toplamında $(t=1,711 ; \mathrm{p}=, 088)$ öğretmen görüşleri incelendiğinde, cinsiyet değişkenine göre erkek ve kadın öğretmenlerin görüşleri arasında anlamlı bir fark bulunmamıştır. Örgütsel sosyalleşmenin “örgüt dili ve tarihi” boyutunda öğretmen görüşleri incelendiğinde, cinsiyet değişkenine göre erkek $(\bar{x}=3,77)$ ve kadın $(\bar{x}=3,60)$ öğretmenlerin görüşleri arasında erkek öğretmenler lehine anlamlı bir fark bulunmuştur. $(t=2,184 ; p=, 030)$.

Öğretmen görüşlerinin okul türü değişkenine göre analizi Tablo 3’te verilmiştir. 
Tablo 3

illkokul ve Ortaokul Öğretmenlerinin Örgütsel Vatandaşlık ve Örgütsel Sosyalleşme Düzeylerine İlişkin Görüşlerinin Okul Türü Değişkenine Göre Analizi

\begin{tabular}{|c|c|c|c|c|c|c|c|c|}
\hline Ölçekler & Boyutlar & Okul Türü & $\mathrm{N}$ & $\bar{x}$ & SS & sd & $\mathrm{t}$ & $\mathrm{p}$ \\
\hline Örgütsel & & İlkokul & 183 & 3,93 &, 52 & & & \\
\hline Vatandaşlık & & Ortaokul & 201 & 3,83 &, 53 & 382 & 1,906 & ,057 \\
\hline \multirow{12}{*}{$\begin{array}{c}\text { Örgütsel } \\
\text { Sosyalleşme }\end{array}$} & \multirow[b]{2}{*}{ Mesleki yeterlik } & Ilkokul & 183 & 4,26 &, 53 & \multirow[b]{2}{*}{370,540} & \multirow[b]{2}{*}{1,765} & \multirow[b]{2}{*}{,078 } \\
\hline & & Ortaokul & 201 & 4,17 & 49 & & & \\
\hline & \multirow{2}{*}{$\begin{array}{l}\text { Kişileraras1 } \\
\text { ilişkiler }\end{array}$} & Ilkokul & 183 & 4,19 & ,50 & \multirow[b]{2}{*}{382} & \multirow[b]{2}{*}{3,529} & \multirow[b]{2}{*}{, $000^{*}$} \\
\hline & & Ortaokul & 201 & 4,00 &, 52 & & & \\
\hline & \multirow{2}{*}{ Örgüt dili ve tarihi } & Ilkokul & 183 & 3,80 &, 75 & \multirow{2}{*}{382} & \multirow{2}{*}{3,374} & \multirow{2}{*}{, $001^{*}$} \\
\hline & & Ortaokul & 201 & 3,54 & 73 & & & \\
\hline & \multirow{2}{*}{ Örgüt politikası } & Ilkokul & 183 & 4,24 &, 52 & \multirow{2}{*}{382} & \multirow{2}{*}{3,249} & \multirow{2}{*}{, $001^{*}$} \\
\hline & & Ortaokul & 201 & 4,07 & ,50 & & & \\
\hline & \multirow{2}{*}{$\begin{array}{l}\text { Amaç ve değerlere } \\
\text { uyum uuuuuyum } \\
\text { uyum }\end{array}$} & Ilkokul & 183 & 4,41 & ,54 & \multirow[b]{2}{*}{382} & \multirow[b]{2}{*}{3,156} & \multirow[b]{2}{*}{, $002^{*}$} \\
\hline & & Ortaokul & 201 & 4,23 & ,56 & & & \\
\hline & \multirow[b]{2}{*}{ Toplam } & İlkokul & 183 & 4,20 & ,44 & \multirow[b]{2}{*}{382} & \multirow{2}{*}{3,843} & \multirow{2}{*}{, $000^{*}$} \\
\hline & & Ortaokul & 201 & 4,02 & 44 & & & \\
\hline
\end{tabular}

${ }^{*} \mathrm{p}<0,05$

Tablo 3’te, örgütsel vatandaşlık davranışlarına yönelik öğretmen görüşleri incelendiğinde, okul türü değişkenine göre ilkokul ve ortaokul öğretmenlerinin görüşleri arasında anlamlı bir fark bulunmamıştır $(\mathrm{t}=1,906 ; \mathrm{p}=, 057)$.

Örgütsel sosyalleşmenin "mesleki yeterlik" boyutunda öğretmen görüşleri incelendiğinde, okul türü değişkenine göre ilkokul ve ortaokul öğretmenlerinin görüşleri arasında anlamlı bir fark bulunmamıştır $(\mathrm{t}=1,765 ; \mathrm{p}=, 078)$. Örgütsel sosyalleşmenin "kişilerarası ilişkiler" boyutunda öğretmen görüşleri incelendiğinde, okul türü değişkenine göre ilkokul $(\bar{x}=4,19)$ ve ortaokul $\left({ }^{\bar{x}}=4,00\right)$ öğretmenlerinin görüşleri arasında ilkokul öğretmenleri lehine anlamlı bir fark bulunmuştur $(t=3,529 ; p=, 000)$. Örgütsel sosyalleşmenin “örgüt dili ve tarihi” boyutunda öğretmen görüşleri incelendiğinde, okul türü değişkenine göre ilkokul $\left({ }^{\bar{x}}=3,80\right)$ ve ortaokul ( $\bar{x}_{=3,54)}$ öğretmenlerinin görüşleri arasında ilkokul öğretmenleri lehine anlamlı bir fark bulunmuştur ( $t=3,374 ; \mathrm{p}=, 001)$. Örgütsel sosyalleşmenin “örgüt politikası” boyutunda öğretmen görüşleri incelendiğinde, okul türü değişkenine göre ilkokul $(\bar{x}=4,24)$ ve ortaokul $(\bar{x}=4,07)$ öğretmenlerinin görüşleri arasında ilkokul öğretmenleri lehine anlamlı bir fark bulunmuştur $(\mathrm{t}=3,249 ; \mathrm{p}=, 001)$. Örgütsel sosyalleşmenin “amaç ve değerlere uyum” boyutunda öğretmen görüşleri incelendiğinde, okul türü değişkenine göre ilkokul $\left({ }^{\bar{x}}=4,41\right)$ ve ortaokul $\left({ }^{\bar{x}}=4,23\right)$ öğretmenlerinin görüşleri arasında ilkokul öğretmenleri lehine anlamlı bir fark bulunmuştur $(\mathrm{t}=3,156 ; \mathrm{p}=, 002)$. Örgütsel sosyalleşmenin toplamında, okul türü değişkenine göre ilkokul ( $\bar{x}=4,20)$ ve ortaokul $\left({ }^{\bar{x}}=4,02\right)$ öğretmenlerinin görüşleri arasında ilkokul öğretmenleri lehine anlamlı bir fark bulunmuştur $(\mathrm{t}=3,843 ; \mathrm{p}=, 000)$.

Öğretmen görüşlerinin branş değişkenine göre analizi Tablo 4’te verilmiştir. 
Tablo 4

Illkokul ve Ortaokul Öğretmenlerinin Örgütsel Vatandaşlık ve Örgütsel Sosyalleşme Düzeylerine Illişkin Görüşlerinin Branş Değişkenine Göre Analizi

\begin{tabular}{|c|c|c|c|c|c|c|c|c|}
\hline Ölçekler & Boyutlar & $\begin{array}{c}\text { Varyansın } \\
\text { kaynağı }\end{array}$ & $\begin{array}{l}\text { Kareler } \\
\text { Toplamı }\end{array}$ & sd & $\begin{array}{c}\text { Kareler } \\
\text { Ort. }\end{array}$ & $\mathrm{F}$ & $\mathrm{p}$ & Fark $^{* *}$ \\
\hline $\begin{array}{c}\text { Örgütsel } \\
\text { Vatandaşlık }\end{array}$ & & $\begin{array}{c}\text { Gruplar arası } \\
\text { Gruplar içi } \\
\text { Toplam }\end{array}$ & $\begin{array}{c}1,393 \\
106,589 \\
107,982\end{array}$ & $\begin{array}{c}2 \\
381 \\
383\end{array}$ & $\begin{array}{l}, 696 \\
, 280\end{array}$ & 2,489 & ,084 & - \\
\hline \multirow{6}{*}{$\begin{array}{c}\text { Örgütsel } \\
\text { Sosyalleşme }\end{array}$} & Mesleki yeterlik & $\begin{array}{c}\text { Gruplar arası } \\
\text { Gruplar içi } \\
\text { Toplam }\end{array}$ & $\begin{array}{c}1,062 \\
100,020 \\
101,082\end{array}$ & $\begin{array}{c}2 \\
381 \\
383\end{array}$ & $\begin{array}{l}, 531 \\
, 263\end{array}$ & 2,022 & , 134 & - \\
\hline & $\begin{array}{l}\text { Kişilerarası } \\
\text { ilişkiler }\end{array}$ & $\begin{array}{c}\text { Gruplar arası } \\
\text { Gruplar içi } \\
\text { Toplam } \\
\end{array}$ & $\begin{array}{c}4,050 \\
102,238 \\
106,288 \\
\end{array}$ & $\begin{array}{c}2 \\
381 \\
383 \\
\end{array}$ & $\begin{array}{r}2,025 \\
, 268\end{array}$ & $7,547^{*}$ & ,001 & $\begin{array}{l}1-2 \\
1-3\end{array}$ \\
\hline & $\begin{array}{l}\text { Örgüt dili ve } \\
\text { tarihi }\end{array}$ & $\begin{array}{c}\text { Gruplar arası } \\
\text { Gruplar içi } \\
\text { Toplam } \\
\end{array}$ & $\begin{array}{c}9,740 \\
209,893 \\
219,633 \\
\end{array}$ & $\begin{array}{c}2 \\
381 \\
383 \\
\end{array}$ & $\begin{array}{r}4,870 \\
, 551\end{array}$ & $8,840^{*}$ & ,000 & $\begin{array}{l}1-2 \\
1-3\end{array}$ \\
\hline & Örgüt politikası & $\begin{array}{c}\text { Gruplar arası } \\
\text { Gruplar içi } \\
\text { Toplam } \\
\end{array}$ & $\begin{array}{c}4,216 \\
100,594 \\
104,810 \\
\end{array}$ & $\begin{array}{c}2 \\
381 \\
383 \\
\end{array}$ & $\begin{array}{r}2,108 \\
, 264\end{array}$ & $7,983^{*}$ & ,000 & $\begin{array}{l}1-2 \\
1-3\end{array}$ \\
\hline & $\begin{array}{l}\text { Amaç ve değerlere } \\
\text { uyum }\end{array}$ & $\begin{array}{c}\text { Gruplar aras1 } \\
\text { Gruplar içi } \\
\text { Toplam }\end{array}$ & $\begin{array}{c}2,746 \\
117,734 \\
120,480\end{array}$ & $\begin{array}{c}2 \\
381 \\
383\end{array}$ & $\begin{array}{r}1,373 \\
, 309\end{array}$ & $4,443^{*}$ & ,012 & $1-2$ \\
\hline & Toplam & $\begin{array}{l}\text { Gruplar arası } \\
\text { Gruplar içi } \\
\text { Toplam }\end{array}$ & $\begin{array}{c}3,675 \\
75,031 \\
78,706\end{array}$ & $\begin{array}{c}2 \\
381 \\
383\end{array}$ & $\begin{array}{r}1,837 \\
, 197\end{array}$ & $9,331^{*}$ & ,000 & $\begin{array}{l}1-2 \\
1-3\end{array}$ \\
\hline
\end{tabular}

$\left({ }^{\star}\right) \mathrm{p}<0,05$

(**) 1: Sınıf Öğretmeni, 2: Sözel Ders Öğretmeni, 3: Sayısal Ders Öğretmeni

Tablo 4’te örgütsel vatandaşlık davranışlarına yönelik öğretmenlerin görüşleri incelendiğinde branş değişkenine göre; sınıf, sözel ders ve sayısal ders öğretmenlerinin görüşleri arasında anlamlı bir fark bulunmamıştır $(\mathrm{F}=2,489 ; \mathrm{p}=, 084)$.

Örgütsel sosyalleşmenin "mesleki yeterlik” boyutunda öğretmen görüşleri incelendiğinde, branş değişkenine göre; sınıf, sözel ders ve sayısal ders öğretmenlerinin görüşleri arasında anlamlı bir fark bulunmamıştır $(\mathrm{F}=2,022 ; \mathrm{p}=, 134)$. Örgütsel sosyalleşmenin "kişilerarası ilişkiler” boyutunda öğretmenlerin görüşleri incelendiğinde, branş değişkenine göre anlamlı bir fark olduğu görülmektedir $(\mathrm{F}=7,547 ; \mathrm{p}=, 001)$. Farkların hangi gruplar arasında olduğunu bulmak amacıyla vapılan Tukey testinin sonuçlarına göre sinıf öğretmenlerinin $(\bar{x}=4,21)$, sözel branşlarda $\left({ }^{\bar{x}}=4,02\right)$ ve sayısal branşlarda görevli öğretmenlere $\left({ }^{\bar{x}}=3,97\right)$ göre örgütsel sosyalleşme davranışları hakkındaki görüşleri daha olumludur. Örgütsel sosyalleşmenin “örgüt dili ve tarihi” boyutunda öğretmenlerin görüşleri incelendiğinde, branş değişkenine göre anlamlı bir fark olduğu görülmektedir $(\mathrm{F}=8,840 ; \mathrm{p}=, 000)$. Farkların hangi gruplar arasında olduğunu bulmak amacıyla yapılan Tukey testinin sonuçlarına göre sinıf öğretmenlerinin $\left(\bar{x}^{\bar{x}}=3,86\right)$, sözel branşlarda $\left({ }^{\bar{x}}=3,53\right)$ ve sayısal branşlarda görevli öğretmenlere $\left({ }^{\bar{x}}=3,54\right)$ göre örgütsel sosyalleşme davranışları hakkındaki görüşleri daha olumludur. Örgütsel sosyalleşmenin “örgüt 
politikası" boyutunda öğretmenlerin görüşleri incelendiğinde, branş değişkenine göre anlamlı bir fark olduğu görülmektedir $(\mathrm{F}=7,983 ; \mathrm{p}=, 000)$. Farkların hangi gruplar arasında olduğunu bulmak amacıyla yapılan Tukey testinin sonuçlarına göre sınıf öğretmenlerinin $\left({ }^{\bar{x}}=4,28\right)$, sözel branşlarda $(\bar{x}=4,06)$ ve sayısal branşlarda görevli öğretmenlere $(\bar{x}=4,07)$ göre örgütsel sosyalleşme davranışları hakkındaki görüşleri daha olumludur. Örgütsel sosyalleşmenin "amaç ve değerlere uyum” boyutunda öğretmenlerin görüşleri incelendiğinde, branş değişkenine göre anlamlı bir fark olduğu görülmektedir $(\mathrm{F}=4,443 ; \mathrm{p}=, 012)$. Farkların hangi gruplar arasında olduğunu bulmak amacıyla yapılan Tukey testinin sonuçlarına göre sınıf öğretmenlerinin $\left({ }^{\bar{x}}=4,42\right)$, sözel branşlarda $\left({ }^{\bar{x}}=4,25\right)$ görevli öğretmenlere göre örgütsel sosyalleşme davranışları hakkındaki görüşleri daha olumludur. Örgütsel sosyalleşmenin toplamında öğretmenlerin görüşleri incelendiğinde, branş değişkenine göre anlamlı bir fark olduğu görülmektedir $(\mathrm{F}=9,331 ; \mathrm{p}=, 000)$. Farkların hangi gruplar arasında olduğunu bulmak amacıyla yapılan Tukey testinin sonuçlarına göre sınıf öğretmenlerinin $\left({ }^{\bar{x}}=4,22\right)$, sözel branşlarda $\left({ }^{\bar{x}}=4,02\right)$ ve sayısal branşlarda görevli öğretmenlere ( $\bar{x}_{=4,02)}$ göre örgütsel sosyalleşme davranışları hakkındaki görüşleri daha olumludur.

İlkokul ve ortaokul öğretmenlerinin örgütsel vatandaşlık ve örgütsel sosyalleşme tutumları arasındaki ilişkilere yönelik korelasyon analizi sonuçları Tablo 5’te verilmiştir.

Tablo 5

Örgütsel Vatandaşlık ve Örgütsel Sosyalleşme Arasındaki Ilişkiye Yönelik Korelasyon Analizi

\begin{tabular}{|c|c|c|c|c|c|c|}
\hline 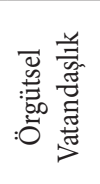 & 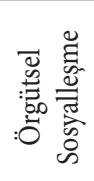 & 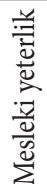 & 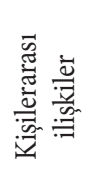 & 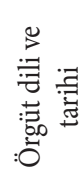 & 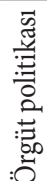 & 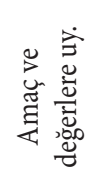 \\
\hline
\end{tabular}

\begin{tabular}{lllllll}
\hline Örgütsel Vatandaşllk & - & & & & & \\
\hline Örgütsel Sosyalleşme &, $48^{* *}$ & - & & & & \\
\hline Mesleki yeterlik &, $34^{* *}$ &, $77^{* *}$ & - & & & \\
\hline Kişilerarası iliş̧kiler &, $44^{* *}$ &, $83^{* *}$ &, $58^{* *}$ & - & & \\
\hline Örgüt dili ve tarihi &, $35^{* *}$ &, $78^{* *}$ &, $45^{* *}$ &, $54^{* *}$ & - & \\
\hline Örgüt politikası &, $34^{* *}$ &, $81^{* *}$ &, $55^{* *}$ &, $55^{* *}$ &, $66^{* *}$ & - \\
\hline Amaç ve değerlere uyum &, $40^{* *}$ &, $78^{* *}$ &, $52^{* *}$ &, $57^{* *}$ &, $43^{* *}$ &, $57^{* *}$ \\
\hline$*$
\end{tabular}

${ }^{* *}$ Korelasyon 0,01 düzeyinde anlamlıdır.

Tablo 5 incelendiğinde öğretmenlerin örgütsel vatandaşlı ile örgütsel sosyalleşme tutumları arasında $(\mathrm{r}=.48, \mathrm{p}<0.01)$ orta düzeyde pozitif yönde anlamlı bir ilişki olduğu görülmektedir. Örgütsel vatandaşlık ile örgütsel sosyalleşmenin alt boyutları kıyaslandığında, örgütsel vatandaşlık ile mesleki yeterlik $(\mathrm{r}=.34, \mathrm{p}<0.01)$, örgütsel vatandaşlık ile kişilerarası ilişkiler $(\mathrm{r}=.44, \mathrm{p}<0.01)$, örgütsel vatandaşlık ile örgüt dili ve tarihi $(\mathrm{r}=.35, \mathrm{p}<0.01)$, örgütsel vatandaşlık ile örgüt politikası $(\mathrm{r}=.34, \mathrm{p}<0.01)$ ve örgütsel vatandaşlık ile amaç ve değerlere uyum $(\mathrm{r}=.40, \mathrm{p}<0.01)$ arasında orta düzeyde pozitif yönde anlamlı bir ilişki olduğu görülmektedir. 
Örgütsel sosyalleşme boyutlarının örgütsel vatandaşlı̆̆ yordamasına ilişkin çoklu regresyon analizi Tablo 6’da verilmiştir.

\section{Tablo 6}

Örgütsel Sosyalleşme Boyutlarının Örgütsel Vatandaşlığı Yordamasına İlişkin Çoklu Regresyon Analizi

\begin{tabular}{llllllll}
\hline Değişkenler & $\mathbf{B}$ & $\begin{array}{l}\text { Standart } \\
\text { Hata }\end{array}$ & $\boldsymbol{\beta}$ & $\mathbf{t}$ & $\mathbf{p}$ & İkili r & Kismi r \\
\hline Sabit & 1,582 &, 235 & & 6,729 &, 000 & & \\
\hline Mesleki yeterlik &, 064 &, 062 &, 062 & 1,038 &, 300 &, 349 &, 053 \\
\hline Kişilerarast ilişkiler &, 242 &, 064 &, 240 & 3,790 &, 000 &, 444 &, 191 \\
\hline Örgüt dili ve tarihi &, 083 &, 044 &, 119 & 1,901 &, 058 &, 352 &, 097 \\
\hline Örgüt politikas1 &,- 007 &, 070 &,- 007 &,- 095 &, 924 &, 347 &,- 005 \\
\hline Amaç ve değerlere uyum &, 177 &, 057 &, 187 & 3,109 &, 002 &, 405 &, 158 \\
\hline $\mathrm{R}=0,493 \mathrm{R}^{2}=0,243$ & & & & & & & \\
$\mathrm{~F}_{(5-378)=} 24,296 \mathrm{p}=, 000$ & & & & & & &
\end{tabular}

Örgütsel vatandaşlık üzerine etkisi olduğu düşünülen, mesleki yeterlik, kişilerarası ilişkiler, örgüt dili ve tarihi, örgüt politikası ile amaç ve değerlere uyum gibi değişkenlerin, örgütsel vatandaşlığı ne şekilde yordadığını ortaya koymaya yönelik olarak yapılan çoklu doğrusal regresyon analizi sonucunda, mesleki yeterlik, kişilerarası ilişkiler, örgüt dili ve tarihi, örgüt politikası ile amaç ve değerlere uyum değişkenleri birlikte, örgütsel vatandaşlık ile anlamlı bir ilişki $\left(R=0,493, R^{2}=0,243\right)$ sergilemişlerdir $\left(F_{(5-378)=} 24,296, p<0,01\right)$. Söz konusu beş değişken, birlikte örgütsel vatandaşlıktaki değişimin \%24’ünü açıklamaktadır. Standartlaştırılmış regresyon katsayılarına göre, yordayıcı değişkenlerin, örgütsel vatandaşlık üzerindeki göreli önem sırası, kişilerarası ilişkiler $(\beta=, 240)$, amaç ve değerlere uyum $(\beta=, 187)$, örgüt dili ve tarihi $(\beta=, 119)$, mesleki yeterlik $(\beta=, 062)$ ve örgüt politikasıdır $(\beta=-, 007)$. Regresyon katsayılarının anlamlılık testleri göz önüne alındığında, yordayıcı değişkenlerden sadece kişilerarası ilişkiler $(p<0,01)$ ile amaç ve değerlere uyum ( $\mathrm{p}<0,01)$ değişkenlerinin, örgütsel vatandaşlı̆̆ın anlamlı yordayıcıları olduğu görülmektedir. Regresyon analizi sonuçlarına göre, örgütsel vatandaşlı̆̆ı yordayan regresyon denklemi şu şekildedir:

Örgütsel vatandaşlık $=(1,582)+(, 064 \mathrm{x}$ mesleki yeterlik $)+(, 242 \mathrm{x}$ kişilerarası ilişkiler $)+(, 083$ $\mathrm{x}$ örgüt dili ve tarihi $)+(-, 007 \mathrm{x}$ örgüt politikası $)+(, 177 \mathrm{x}$ amaç ve değerlere uyum $)$

\section{Sonuç, Tartışma ve Öneriler}

Erzurum ili merkez Yakutiye ilçesinde görev yapan 384 ilkokul ve ortaokul öğretmeninin görüşleri alınarak, öğretmenlerin örgütsel vatandaşlık ve örgütsel sosyalleşme davranışlarını belirleme amaçlı araştırma sonucunda aşağıdaki sonuçlara ulaşılmıştır. 
İlkokul ve ortaokul öğretmenlerinin örgütsel vatandaşlık davranışlarını sergileme düzeylerine ilişkin görüşleri ile cinsiyetleri arasında anlamlı bir farklılık yoktur. Bu bulguya benzer şekilde Yılmaz ve Taşdan (2009) ve Aydın (2017)'ın çalışmalarında da cinsiyet değiş̧enine göre anlamlı bir fark bulunmamıştır. Bulut (2011)'un çalışmasında örgütsel vatandaşlığın centilmenlik ve sivil erdem boyutlarında erkekler lehine, Garg ve Rastogi (2006)'nin çalışmalarında ise kadınlar lehine anlamlı fark bulunmuştur.

Örgütsel sosyalleşmenin "mesleki yeterlik", "kişilerarası ilişkiler", "örgüt politikası", "amaç ve değerlere uyum" boyutları ve örgütsel sosyalleşmenin toplamında cinsiyet değişkenine göre öğretmenlerin görüşleri arasında anlamlı bir fark bulunamamıştır. Örgütsel sosyalleşmenin “örgüt dili ve tarihi” boyutunda cinsiyet değişkenine göre öğretmenlerin görüşleri arasında erkek öğretmenler lehine anlamlı bir fark bulunmuştur. Bu boyutta farkın sebebi erkek öğretmenlerin kurumlarının geçmişi, gelenekleri ve kurumlarına özgü sözcükleri öğrenme konusundaki ilgileri olabilir. Bu bulguya benzer olarak Dönmez (2016)'in çalışmasında da örgütsel sosyalleşmenin "örgüt dili ve tarihi” boyutunda erkek öğretmenler lehine anlamlı fark bulunmuştur. Erdoğan (2012) çalışmasında örgütsel sosyalleşmenin "mesleki yeterlik" boyutunda kadın öğretmenler lehine; "örgüt dili ve tarihi” boyutunda ise erkek öğretmenler lehine anlamlı fark bulunmuştur. Yıldırım (2017)'ın çalışmasında ise örgütsel sosyalleşmenin “örgüt dili ve tarihi”, "amaç ve değerlere uyum" boyutları ile örgütsel sosyalleşmenin toplamında erkek öğretmenler lehine anlamlı fark bulunmuştur. Vural (2015) ile Demirtaş ve Zeynep (2015)'nn çalışmalarında ise, örgütsel sosyalleşmenin tüm boyutlarında cinsiyet değişkenine göre anlamlı bir fark bulunamamıştır.

İlkokul ve ortaokulöğretmenlerinin örgütsel vatandaşlık davranışlarına sahip olma düzeylerine ilişskin görüşleri ile okul türü arasında anlamlı bir farklılık yoktur. Bu bulguya benzer şekilde Aydın (2017)'ın çalışmasında ise okul türü değişkenine göre anlamlı bir fark bulunamamıştır. Korkmaz ve Arabacı (2013)'nın çalı̧̧malarında ise örgütsel vatandaşlı̆̆ın yardımseverlik ve nezaket boyutlarında ilköğretim okulu öğretmenleri lehine anlamlı fark bulunmuştur.

Örgütsel sosyalleşmenin "kişilerarası ilişkiler”, "örgüt dili ve tarihi”" "örgüt politikası", "amaç ve değerlere uyum" boyutları ve örgütsel sosyalleşmenin toplamında okul türü değişkenine göre öğretmenlerin görüşleri arasında ilkokul öğretmenleri lehine anlamlı bir fark bulunmuştur. Örgütsel sosyalleşmenin toplamında ve bu boyutlarda farkın sebebi ilkokul öğretmenlerinin ortaokul öğretmenlerine göre kendilerini kurumlarıly daha fazla özdeşleştirmeleri olabilir. Örgütsel sosyalleşmenin "mesleki yeterlik" boyutunda okul türü değişkenine göre öğretmenlerin görüşleri arasında anlamlı bir fark bulunamamıştır. Vural (2015)'in çalışmasında örgütsel sosyalleşmenin "mesleki yeterlik" boyutunda ilkokul öğretmenleri lehine anlamlı fark bulunmuştur. Demirtaş ve Zeynep (2015)'n çalışmasında ise, örgütsel sosyalleşmenin tüm boyutlarında ve sosyalleşmenin genelinde okul türü değişkenine göre anlamlı bir farklılık bulunmamıştır.

İlkokul ve ortaokul öğretmenlerinin örgütsel vatandaşlık davranışlarına sahip olma düzeylerine ilişskin görüşleri ile branşları arasında anlamlı bir farklılık yoktur. Benzer şekilde Yllmaz ve Taşdan (2009)'ın çalışmalarında da branş değişkenine göre anlamlı bir fark bulunmamıştır. Aydın 
(2017)'ın çalışmasında örgütsel vatandaşlığın sportmenlik boyutunda sınıf öğretmenleri lehine, Bulut (2011)'un çalışmasında ise örgütsel vatandaşlığın yardımlaşma, vicdanlılık ve sivil erdem boyutlarında branş öğretmenleri lehine anlamlı fark bulunmuştur.

Örgütsel sosyalleşmenin "kişilerarası ilişkiler", “örgüt dili ve tarihi”, “örgüt politikası" boyutları ve örgütsel sosyalleşmenin toplamında branş değiş̧enine göre öğretmenlerin görüşleri arasında anlamlı bir fark bulunmuştur. Örgütsel sosyalleşmenin bu boyutlarında ve örgütsel sosyalleşmenin toplamında sınıf öğretmenlerinin örgütsel sosyalleşme düzeylerinin sözel ders öğretmenleri ve sayısal ders öğretmenlerinin örgütsel sosyalleşme düzeylerinden daha olumlu olduğu görülmektedir. Örgütsel sosyalleşmenin "amaç ve değerlere uyum" boyutunda branş değişkenine göre öğretmenlerin görüşleri arasında anlamlı bir fark bulunmuştur. Bu boyutta sınıf öğretmenlerinin örgütsel sosyalleşme düzeylerinin sözel ders öğretmenlerinin örgütsel sosyalleşme düzeylerinden daha olumlu olduğu görülmektedir. Örgütsel sosyalleşmenin toplamında ve bu boyutlarda farkın sebebi sını öğretmenlerinin kendilerini kurumlarıyla daha fazla özdeşleştirmeleri olabilir. Örgütsel sosyalleşmenin "mesleki yeterlik" boyutunda branş değişkenine göre öğretmenlerin görüşleri arasında anlamlı bir farklılık bulunamamıştır. Erdoğan (2012)'n çalışmasında ise örgütsel sosyalleşmenin "örgüt politikası" dışında diğer boyutlarda ve örgütsel sosyalleşmenin genelinde sınıf ve branş öğretmenleri arasında sınıf öğretmenleri lehine anlamlı fark bulunmuştur. Vural (2015)'in çalışmasında ise örgütsel sosyalleşmenin 'örgüt politikası" boyutunda branş öğretmenleri lehine anlamlı fark bulunmuştur. Demirtaş ve Zeynep (2015)'in çalışmasında ise, örgütsel sosyalleşmenin "örgüt tarihi ve dili" boyutu dışındaki bütün boyutlarda sosyal branş öğretmenleri lehine anlamlı fark bulunmuştur.

İlkokul ve ortaokul öğretmenlerinin örgütsel vatandaşl1k ile örgütsel sosyalleşme tutumları arasında orta düzeyde, pozitif yönde anlamlı bir ilişki olduğu tespit edilmiştir. Başka bir değişle, öğretmenlerin sosyalleşme düzeyleri arttıkça örgütsel vatandaşlık tutumları da artmaktadır. Bu bulguya benzer olarak Yıldırım (2017)'ın çalışmasında da örgütsel vatandaşlık ile örgütsel sosyalleşme arasında orta düzeyde, pozitif yönde anlamlı bir ilişki tespit edilmiştir.

Öğretmenlerin örgütsel vatandaşlık ve örgütsel sosyalleşmeleri arasında orta düzeyde, pozitif yönde anlamlı bir ilişki olduğu görülmektedir. Örgütsel vatandaşlı düzeyine ilişkin toplam varyansın \%24'ü öğretmenlerin örgütsel sosyalleşme düzeyleriyle açıklanabilmektedir. Başka bir değişle, öğretmenlerin sosyalleşme düzeyleri arttıkça örgütsel vatandaşlık tutumları da artmaktadır. Regresyon katsayılarının anlamlılık testleri göz önüne alındığında, yordayıcı değişkenlerden sadece kişilerarası ilişkiler $(\mathrm{p}<0,01)$ ile amaç ve değerlere uyum $(\mathrm{p}<0,01)$ değişkenlerinin, örgütsel vatandaşlık üzerinde anlamlı yordayıcı olduğu görülmektedir. $\mathrm{Bu}$ bulguya benzer olarak Yıldırım (2017)'ın çalışmasında da örgütsel vatandaşlık ile örgütsel sosyalleşme arasında orta düzeyde, pozitif yönde anlamlı bir ilişki tespit edilmiştir.

Araştırma sonucu elde edilen bulgulara göre aşağıdaki öneriler yapılabilir:

Okul yöneticileri ve kıdemli öğretmenler, okula yeni gelen öğretmenlerin mesleki yeterliliklerinin artırılmasında, okul değerlerine uyumlarının sağlanması hususunda çaba gösterebilmelidir. 
Okul yöneticileri, öğretmenlerin kurumlarına uyum sağlayabilmeleri açısından gerçekleştirilecek her türlü etkinliğe (okul gezileri, kurul toplantıları, okul-aile birliği toplantıları, mesleki kurslar vs.) katılmalarını teşvik edebilmelidir.

Öğretmenlerin kurumlarında örgütsel vatandaşlık davranışlarını sergilemelerini teşvik edecek bir mekanizma oluşturulmalı; bu doğrultuda örgütsel vatandaşlık davranışları gösteren öğretmenlere kariyerlerinde yükselme, okul yöneticilerinin seçiminde öncelikle bu öğretmenleri tercih etme, onlara akademik gelişim imkanı sağlama gibi yaklaşımlar sergilenebilmelidir. 


\section{Kaynaklar}

Aknar, A. (2013). Otel işletmesi çalışanlarının örgütsel sosyalleşme düzeyleri üzerine bir araştırma. (Yayımlanmamış yüksek lisans tezi). Gazi Üniversitesi Eğitim Bilimleri Enstitüsü, Ankara.

Allison, B. J., Voss, R. S., \& Dryer, S. (2001). Student classroom and career success: The role of organizational citizenship behavior. Journal of Education for Business, 76(5), 282-288.

Aydın, Y. T. (2017). İlkokul ve ortaokul öğretmenlerinin örgütsel sinizm ile örgütsel vatandaşlık davranışı ilişkisi: Ankara Atındă̆ İlçesi Örneği. (Yayınlanmamış yüksek lisans tezi). Balıkesir Üniversitesi SBE, Balıkesir.

Balcı, A. (2003). Örgütsel sosyalleşme: Kuram strateji ve taktikler.(2. Baskı). Ankara: Pegem A Yayıncılık.

Bukhari, Z. U. (2008). Key antecedents of organizational citizenship behavior (OCB) in the banking sector of Pakistan. International Journal of Business and Management, 3(12), 106-115.

Bullis, C. (1993). Organizational socialization research: Enabling, constraining, and shifting perspectives. Communications Monographs, 60(1), 10-17.

Bulut, M. Ş. (2011). İlköğretim okullarındaki performans yönetimi uygulamaları ile örgütsel vatandaşlık davranışı arasındaki ilişki. (Yayınlanmamış yüksek lisans tezi). Sakarya Üniversitesi SBE, Sakarya.

Büyüköztürk, Ş., Çakmak, E. K., Akgün, Ö. E., Karadeniz, Ş. ve Demirel, F. (2016). Bilimsel araştırma yöntemleri. (22. Baskı). Ankara: Pegem Akademi.

Can, H. (1999). Organizasyon ve yönetim.(5. Bask1), Ankara: Siyasal Kitabevi.

Can, H., Azizoğlu, Ö. A. ve Aydın, E. M. (2011). Organizasyon ve yönetim.(8. Baskı). Ankara: Siyasal Kitabevi.

Çalık, T. (2003). İşgörenlerin Örgüte Uyumu (Örgütsel Sosyalleşme), Türk Eğitim Bilimleri Dergisi, 1 (2): 163-177.

Çelik, V.(1998). Alan dışından gelen sınıf öğretmenlerinin örgütsel sosyalizasyonu. Kuram ve Uygulamada Egitim Yönetimi Dergisi 4.2: 191-208.

Çetin, M., Yeşilbağ, Y. ve Akdağ, B. (2003). Öğretmenlerin örgütsel vatandaşlık davranışı. M.Ü. Atatürk Eğitim Fakültesi Eğitim Bilimleri Dergisi, 17, 39-54.

Demirel, Y., Seçkin, Z. ve Özçınar, M. F. (2011). Örgütsel iletişim ile örgütsel vatandaşlık davranışı arasındaki ilişki üzerine bir araştırma. Çukurova Üniversitesi Sosyal Bilimler Enstitüsü Dergisi, 20(2), 33-48.

Demiröz, S. (2014). The relationship between the teachersorganizational citizenship behavior, organizational image perceptions and the student's success. Yayımlanmamış doktora tezi, Hacettepe Üniversitesi EBE, Ankara.

Demirtaş, H. ve Zeynep, U. (2015). Aday öğretmenlerin örgütsel sosyalleşmeleri ile kendini ayarlama becerileri arasındaki ilişki. Kastamonu Ĕ̆itim Dergisi, 24(1), 163-182.

DiPaola, M. F. \& Tschannen-Moran, M. (2001). Organizational citizenship behavior in schools and its relationship to school climate. Journal of School Leadership, 11, 424-447.

DiPaola, M. F., \& Hoy, W. K. (2005). Organizational citizenship of faculty and achievement of high school students. The high school journal, 88(3), 35-44.

DiPaola, M. F., Tarter, C. J. \& Hoy, W. K. (2005). Measuring organizational citizenship in schools: The OCB scale. In W. K. Hoy \& C. Miskel (Eds.). Educational Leadership and Reform (319-342). Greenwich, $\mathrm{CN}$ : Information Age.

Doğan, İ. (2011). Eğitim sosyolojisi. Ankara: Nobel Akademik Yayınc1lık.

Doğrul, M. A. (2013). Örgütsel bağlllık ve örgütsel vatandaşlık davranışı arasındaki ilişki: Afyon Meslek Yüksek Okulu’nda çalışanlar üzerinde bir araştırma. (Yayımlanmamış yüksek lisans tezi). Afyon Kocatepe Üniversitesi SBE, Afyonkarahisar. 
Dönmez, E. (2016). Örgütsel sosyalleşme ile örgütsel sessizlik arasındaki ilişki. (Yayımlanmamış yüksek lisans tezi). Pamukkale Üniversitesi Eğitim Bilimleri Enstitüsü, Denizli.

Erdoğan, U. (2012). İlköğretim okullarının bürokratik yapıları ile öğretmenlerin örgütsel sosyalleşme düzeyleri arasındaki ilişki (Malatya İli Örneği). (Yayımlanmamış yüksek lisans tezi). İnönü Üniversitesi Eğitim Bilimleri Enstitüsü, Malatya.

Eren, E. (2014). Örgütsel davranışve yönetim psikolojisi.(14. Baskı). İstanbul: Beta Basım Yayım Dağıtım.

Ergün, E. ve Taşgit, Y. E. (2011). Örgütsel sosyalleşme taktiklerinin sosyalleşme çıktıları üzerindeki etkisine yönelik bir araştırma. Dumlupınar Üniversitesi Sosyal Bilimler Enstitüsü Dergisi, 31, 97-112.

Esgin, A. (2014). Sosyalleşme. Özdemir, M. Ç. (Ed.), Eğitim sosyolojisi (s. 67-103). Ankara: Pagem Akademi.

Feldman, D.C. (1976). A contingency theory of socialization. Administrative Science Quarterly, 21, 433-452.

Garg, P., \& Rastogi, R. (2006). Climate profile and OCBs of teachers in public and private schools of India. International Journal of Educational Management, 20(7), 529-541.

Ge, J., Su, X., \& Zhou, Y. (2010). Organizational socialization, organizational identification and organizational citizenship behavior: An empirical research of Chinese high-tech manufacturing enterprises. Nankai Business Review International, 1(2), 166-179.

Gök, E. E. (2007). Örgütsel kültür bağlamında örgütsel vatandaşlık olgusu ve bir araştırma. Yayımlanmamış yüksek lisans tezi, Pamukkale Üniversitesi SBE, Denizli.

Gürbüz, S. (2013). Kişi-örgüt uyumu, sosyalizasyon ve iş dizaynı uygulamaları. Sığrı, Ü. ve Gürbüz, S. (Ed.), Örgütsel davranış. (s.175-216). İstanbul: Bata Yayınları.

Güven, M. (2006). Örgütsel bağlllık ve örgütsel vatandaşlık davranışı arasındaki ilişki. (Yayımlanmamış yüksek lisans tezi). Marmara Üniversitesi SBE, İstanbul.

Karasar, N. (2012). Bilimsel araştırma yöntemi. Ankara: Nobel.

Kartal, S. (2008). Eğitim çalışanlarının örgütsel sosyalleşmelerinde ilköğretim okulu yöneticilerinin katkıları ve iki örnek olay. İnönü Üniversitesi Eğitim Fakültesi Dergisi, 9 (15), 75-88.

Kırel, Ç. (2010). İş ilişkileri, kariyer ve toplumsallaşma sürecinde kariyerin önemi. Özkalp, E. (Ed.), Örgütsel davranış. (s. 279-288). Eskişehir: Anadolu Üniversitesi Yayınları.

Korkmaz, C. ve Arabacı, İ. B. (2013). İlköğretim ve ortaöğretim okulları öğretmenlerinin örgütsel vatandaşlık algıları (Malatya İli Örneği). İlköğretim Online, 12 (3), 770-783.

Memduhoğlu, H. B. (2008). Örgütsel sosyalleşme ve türk eğitim sisteminde örgütsel sosyalleşme süreci. Yüzüncü Yıl Üniversitesi Eğitim Fakültesi Dergisi, 5 (2), 137 - 153

Oktay, M. (2000). Davranış bilimlerine giriş. İstanbul: Der Yayınları.

Organ, D. W. (1988). Organizational citizenship behavior: The good soldier syndrome. Lexington Books/DC Heath and Company.

Organ, D. W., Podsakoff, P. M., \& MacKenzie, S. B. (2006). Organizational citizenship behavior: Its nature, antecedents, and consequences. USA: Sage Publications, Inc.

Ostroff, C., \& Rothausen, T. J. (1997). The moderating effect of tenure in person-environment fit: a field study in educational organizations. Journal of Occupational and Organizational Psychology, 70(2), 173-188.

Özdemir, A. (2010). İlköğretim okullarında algılanan yönetici desteğinin ve bireycilik-ortaklaşa davranışçılığın örgütsel vatandaşlık davranışı ile ilişkisi. Kuram ve Uygulamada Eğitim Yönetimi, 16(1), 93-112.

Özdevecioğlu, M. (2003). Örgütsel vatandaşlık davranışı ile üniversite öğrencilerinin bazı demografik özellikleri ve akademik başarıları arasındaki ilişkilerin belirlenmesine yönelik bir araştırma. Erciyes Üniversitesi İktisadi ve İdari Bilimler Fakültesi Dergisi, (20), 117-135. 
Özgan, H. (2013). Stajyer öğretmenlerin sosyalleşme sürecinde okul yöneticilerinden beklentileri. Eğitim ve Bilim, 38(168), 17-29.

Podsakoff, P. M., MacKenzie, S. B., Paine, J. B., \& Bachrach, D. G. (2000). Organizational citizenship behaviors: A critical review of the theoretical and empirical literature and suggestions for future research. Journal of management, 26(3), 513-563.

Polat, S. (2007). Ortaöğretim öğretmenlerinin örgütsel adalet algıları, örgütsel güven düzeyleri ile örgütsel vatandaşlık davranışları arasındaki ilişki. (Yayınlanmamış doktora tezi). Kocaeli Üniversitesi SBE, Kocaeli.

Saks, A. M., \& Ashforth, B. E. (1997). Organizational socialization: Making sense of the past and present as a prologue for the future. Journal of vocational Behavior, 51(2), 234-279.

Sezgin, F. (2005). Örgütsel vatandaşlık davranışları: Kavramsal bir çözümleme ve okul açısından bazı çıarımlar. Gazi Eğitim Fakültesi Dergisi, 25 (1), 317-339.

Sharma, J. P., Bajpai, N., \& Holani, U. (2011). Organizational citizenship behavior in public and private sector and its impact on job satisfaction: A comparative study in Indian perspective. International Journal of Business and Management, 6(1), 67-75.

Somech, A., \& Drach-Zahavy, A. (2000). Understanding extra-role behavior in schools: The relationships between job satisfaction, sense of efficacy, and teachers' extra-role behavior. Teaching and Teacher Education, 16(5), 649-659.

Taştan, M. ve Yllmaz, K. (2008). Organizational citizenship and organizational justice scales' adaptation to Turkish. TED Eğitim ve Bilim Dergisi. 33 (150), 87-96.

Ürek, D. (2015). Sağlık kurumlarında lider-üye etkileşim düzeyi ve örgütsel vatandaşlık davranışı arasındaki ilişkinin değerlendirilmesi. (Yayınlanmamış yüksek lisans tezi). Hacettepe Üniversitesi SBE, Ankara.

Van Maanen, J. (1978). People processing: Strategies of organizational socialization. Organizational dynamics, 7(1), 19-36.

Vural, F. (2015). İlkokul ve ortaokul yönetici ve öğretmenlerinin örgütsel sosyalleşme düzeylerinin incelenmesi (İzmir İli Örneği). (Yayımlanmamış yüksek lisans tezi). Okan Üniversitesi Sosyal Bilimler Enstitüsü, İstanbul.

Walz, S. M., \& Niehoff, B. P. (2000). Organizational citizenship behaviors: Their relationship to organizational effectiveness. Journal of Hospitality \& Tourism Research, 24(3), 301-319.

Yıldırım, Ç. (2017). Lise öğretmenlerinin örgütsel vatandaşlık davranışlarının yordayıcısı olarak örgütsel sosyalleşme. (Yayımlanmamış yüksek lisans tezi). İstanbul Sabahattin Zaim Üniversitesi SBE, İstanbul.

Yıldız, K. (2012). İlköğretim okulu yöneticilerinin örgütsel sosyalleşme sürecinde sosyalleştirme stratejilerini kullanma düzeyleri. Abant İzzet Baysal Üniversitesi Eğitim Fakültesi Dergisi, 12(2), 333-355.

Yllmaz, K. ve Taşdan, M. (2009). Organizational citizenship and organizational justice in Turkish primary schools. Journal of Educational Administration, 47(1), 108-126.

Yüksel, Ö. (2004). İnsan kaynakları yönetimi.(5. Baskı). Ankara: Gazi Kitapevi. 